\title{
ANALYSIS OF NET FARM INCOME AND NON-FARM INCOME OF BROILER FARMERS ACROSS DIFFERENT SCALE OF PRODUCTION IN IMO STATE, NIGERIA
}

\author{
${ }^{1}$ Anyaegbu, C. N., ${ }^{1}$ Ibekwe, U. C., ${ }^{1}$ Odii, M.A.C.A., ${ }^{1}$ Ehirim, N.C., ${ }^{1}$ Chikezie, C., \\ ${ }^{1}$ Ogbonna, S.E. and ${ }^{2}$ Chukwurah, V.C. \\ ${ }^{1}$ Department of Agricultural Economics, Federal University of Technology, Owerri, Nigeria \\ ${ }^{2}$ Department of Agricultural Economics, Ext. and Rural Development, Imo State University, Owerri \\ Corresponding e-mail: casmiranyaegbu@gmail.com
}

\begin{abstract}
This study analyzed net farm income and non-farm income of broiler farmers across different scale of production in Imo State, Nigeria. Capital accumulation for reinvestment and expansion remains a challenge among broiler farmers in the study area. A multi-stage sampling technique was adopted, and a total of 9 LGAs were purposively selected from the 3 zones (Orlu, Owerri and Okigwe zone). Stratified random sampling was used in selecting 26 small-scale and 9 medium-scale farmers from Owerri Agricultural zone for the study. In Orlu, 15 small-scale, 15 medium-scale and 6 large-scale of broiler farmers were selected, while 15 small-scale, 11 medium-scale and 3 large-scale broiler farmers were selected from Okigwe Zone. This gave a total of 113 broiler farmers selected from the chosen LGA's in the state. Out of 113 broiler farmers selected only a total of 100 responses were found useful for the study. Descriptive statistics, profitability ratio and net income model tools were employed for analyses in this study. The profitability result revealed that the large-scale broiler production has the highest return on naira used with $174 \%$ followed by medium-scale production with $47 \%$ return on naira used and the least was small-scale production with $33 \%$ return on naira expended. The result reveals that broiler farming in the study area is profitable and has the ability to offset its own cost, and still generate substantial return on naira used from every additional $\$ 1$ spent no matter the scale of operation. The study also shows that net farm income of broiler farmers (\$7,690,429.50 for small-scale, \$17,615,997.00 for medium-scale and 142,674,200.00 for large-scale) is significantly greater than their non-farm income irrespective of scale of operation. In an attempt to raise the net-income of broiler farmers vis-a-vis more capital to scale-up broiler production, small and medium-scale operators are encouraged to diversify their productions with other livestock enterprises like layer production enterprise, turkey production enterprise and goat production enterprise.
\end{abstract}

Keywords: Net farm income, non-farm income, broilerfarmers, scale of production https://dx.doi.org/10.4314/jafs.v18i2.7

\section{INTRODUCTION}

Despite the huge natural resource endowment and agricultural potential of most farmers in Nigeria, low income is prevalent (International Fund for Agricultural Development, (IFAD), Journal of the Faculty of Agriculture and Veterinary Medicine, Imo State University Owerri website: www ajol.info; Attribution: Non-commercial CC BY-NC 
(2001)). Ehirim et al., (2017) have described low income as a rural phenomenon in Nigeria and in Imo State in particular. Empirical evidence suggests that good number of small holder farmers belong to low-income class who cannot adjust their scale of production (IFAD, 2001; and Ehirim et al., 2017).

Poultry production, which occupies a pride place in agricultural activities given its high and faster turnover rate, is not left out. According to SAHEL (2015) the Nigerian poultry industry comprises about 180 million birds maintaining the second largest chicken population in Africa after South Africa. It is by far largest livestock group and it is estimated to be about 192,689 tonnes in 2018 growing at an average annual rate of $2.88 \%$ (Knoema, 2018). More so, broiler production is an important poultry enterprise required for quality meat production and has majority of the farmers as small holder operators who can neither acquire improved farm input nor access large capital given their poor socio-economic disposition (Mgbakor \& Nzeadachie, 2013).

Furthermore, a large number of small-scale broiler farmers and the persistent low income among them suggest that the transition to large-scale broiler investment has remained a mirage in Nigeria (Babalola, 2014; Ibekwe, 2010, Ike \& Ugwumba, 2011; Mgbakor \& Ezeadachie, 2013). The concomitant low farm income affects farmers' ability to venture into modern business enterprise. Broiler farmers in Nigeria are challenged with low capital accumulation and poor reinvestment; hence only small-scale based farming dominates the study area (Babalola, 2014; Ike \& Ugwumba, 2011; Mgbakor \& Nzeadachie, 2013; Okonkwo \& Akubuo, 2001).

In the past, farming was the major if not the sole preoccupation of most rural dwellers. Nowadays, rural dwellers have multiple streams of income from different facet of economic activities. Thus, one of the most important sources of these incomes could be referred to as "rural non-farm economic sectors/activities". This sector has recorded substantial growth over the past decade in household employment outside own farming (Ibekwe, 2010; Nwaru, 2007). At present, due to the increasing share of non-farm incomes, they cannot be considered as marginal (Ibekwe, 2010).

\section{MATERIALS AND METHOD}

The study was conducted in Imo State of Nigeria. The state is made up of twenty-seven (27) Local Government Areas. These Local Government Areas fall into three agricultural zones namely; Owerri, Okigwe and Orlu Zones. Eleven local government areas make up Owerri agricultural zone which are limited to Ezinihitte Mbaise, Ahiazu Mbaise, Aboh Mbaise, Owerri North, Owerri West, Mbaitoli, Ikeduru, Owerri Municipal, Ngor-Okpala, Oguta and Ohaji/Egbema. Six local government areas make up Okigwe agricultural zone which are limited to Obowu, Ihite Uboma, Isiala Mbano, Ehime Mbano, Onuimo and Okigwe- While Orlu agricultural zone is made up of ten local government areas which include: Ideato South, Ideato North, Oru East, Oru West, Orsu, Orlu, Isu, Nwangele, Nkwere and Njaba. Imo State was 
chosen for this study because broiler farming offers a great deal of means of livelihood to a lot of its residents.

The study used a multistage sampling technique. The three (3) Agricultural Zones; Okigwe, Orlu and Owerri, were used to ensure proper representation of broiler farmers in the state. A list of broiler farmers and their stock sizes in the state from Agricultural Development Programme (ADP) showed that some local government areas do not have any registered broiler farmers. Hence, a purposive selection of three (3) Local Government Areas (LGAs) with large number of registered broiler farmers from each zone was done in the first stage. Hereafter, Ezinihitte Mbaise, Oguta and Ikeduru LGAs were selected from Owerri Agricultural Zone, and Nwangele, Orlu and Oru East were selected from Orlu Agricultural Zone, while Okigwe, Isiala Mbano and Obowo LGAs were selected from Okigwe Agricultural zone. The registered LGA's is shown in Table 1.0.

The second stage was disaggregation of the farmers according to their stock sizes which represent their scale of operation. The categorization into three scale of operations follows Olorunsanya (2004), and Akinwumi, Adegeye, Ikpi, and Olayide (1979) classification who established that a farmer who maintains at least 5000 birds is classified a large-scale producer and farmers with between 500 and 4999 birds are medium-scale producers, while those with less than 500 birds are said to be small-scale producers. A stratified random sampling technique was used to select 113 broiler farmers from across the already selected LGA's in the state. At this stage, 35 broiler farmers were chosen from Owerri agricultural Zone while 42 and 36 were selected from Okigwe and Orlu respectively. The stratification was done followed by a proportionate random selection. This is due to the unequal number of broiler farmers in each stratum. In Owerri Agricultural Zone, 26 small-scale and 9 medium-scale of broiler farmers were selected for the study as there are no large-scale broiler farmers. In Orlu, 15 small and mediumscale each and 6 large-scale of broiler farmers were selected. While 15, 11, and 3 of broiler farmers were chosen for small-scale, medium-scale and large-scale respectively from Okigwe Zone.

A well-structured questionnaire was administered to these farmers to elicit information on their operations such as unit prices of input and output, scale of production, revenue, other sources of income. The study retrieved a total of 100 responses from these farmers. In Owerri Zone, only 35 responses of 26 and 9 from small and medium-scale farmers respectively were found useful for data analysis. In Orlu, all the 36 questionnaires comprising of 15 each of small and mediumscale and 6 from large-scale broiler farmers were found useful. In Okigwe, only 29 out of 42 responses were found useful for the study. The detail distribution of questionnaire and their retrieved responses are shown in Table 1.0.

\section{Estimating the Net Farm Income}

Net farm income model was used to achieve the objective of this study. In this study, net farm income is classified across the different scale of broiler operation in the study area. Net farm Journal of the Faculty of Agriculture and Veterinary Medicine, Imo State University Owerri website: www ajol.info; Attribution: Non-commercial CC BY-NC 
income (NFI) analysis was used to compute the costs, returns and profitability of broiler production in the study area. The net farm income model of broiler farmers is specified below following Emaikwu, Chikwendu and Sani (2011).

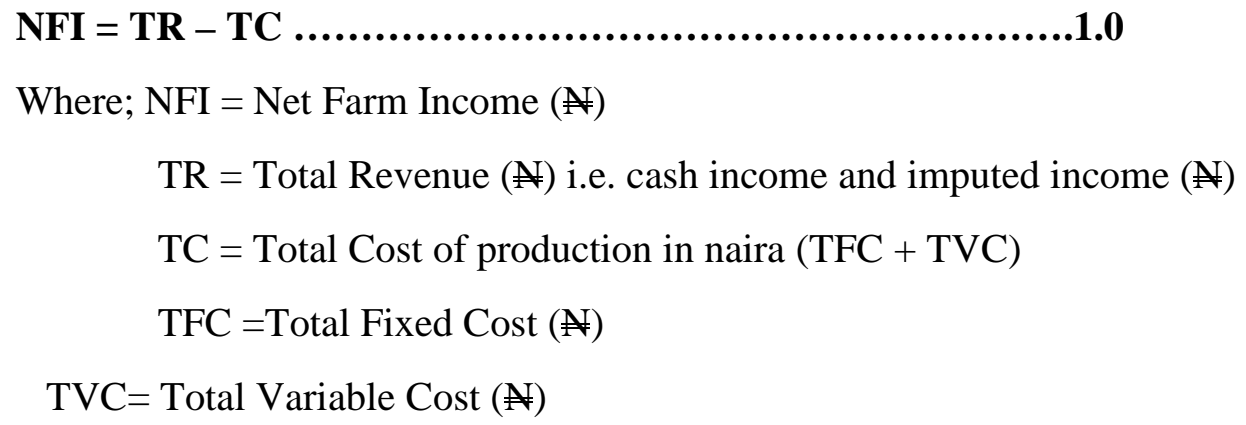

\section{RESULTS AND DISCUSSION}

\section{Net Farm Income of Broiler Farmers Across Different Scale of Production}

The annual net income of the broiler farmers across the small, medium and large-scale operations were illustrated in Table 2.0. The volume of revenue generated from sales of broilers by small-scale operators amount to $\$ 30,781,560.00$ per annum. However, the cost outlays for small-scale farmers include depreciation cost of $\$ 727,487.50$, operating cost which was $\$ 19,445,343.00$, interest on farm loan at $\$ 306,500$ and imputed cost from family occupied pen at $\$ 1,262,100.00$ and family labour at $\$ 1,349,700.00$. The total cost of the entire production activities for small-scale broiler farming enterprise amount to 23,091,130.50. With the net income model analysis, the annual net income of small-scale broiler farmers in the study area amount to $\mathbf{N} 7,690,429.50$ while the average net income per bird is $\mathrm{N} 252.73$ with $33 \%$ return on naira used. That is to show that the small-scale broiler farmers in the study will be generating an average net income of $\$ 252.73$ per bird raised in a cycle. This also indicates that for every additional $\mathrm{N} 1$ used in the small-scale broiler farming in the study area, there will be $33 \%$ increase in return on naira used at the end of the year, all things being equal. Thus, small-scale broiler production in the study area is profitable.

Similarly, medium-scale broiler farmers generated a good sum of revenue from the sale of broilers at the tune of $\$ 54969250.00$ per annum. Whereas the cost implications of the production activities include depreciation cost of 760,588.00, operating cost of $\$ 33,063,165.00$ and interest on loan borrowed is given at $\$ 145,000.00$. While the imputed cost on family occupied broiler pen amount to $\$ 1,457,750.00$ and that of family labour summed up to $\$ 1,926,750.00$. These sum the total cost of the entire production activities for medium-scale broiler enterprise to $\$ 37,353,253.00$. With the net income model, the annual net income of medium-scale broiler farmers in the study area amount to 17,615,997.00, while the average net income per bird is $\$ 171.45$ with $47 \%$ return on naira used. That is to show that the mediumscale broiler farmers in the study will be generating an average net income of 171.45 per bird Journal of the Faculty of Agriculture and Veterinary Medicine, Imo State University Owerri website: www ajol.info; Attribution: Non-commercial CC BY-NC 
raised in a cycle. Table 2.0 also indicates that for every additional $\mathrm{N} 1$ used in the medium-scale broiler farming in the study area, there will be $47 \%$ increase in return on naira used at the end of the year, all things being equal. Thus, medium-scale broiler production in the study area is more profitable relative to small-scale broiler production.

However, large-scale of broiler farmers generate a large volume of revenue at the tune of $\$ 224,852,500.00$ per annum. The cost implications of the production activities include depreciation cost of $\$ 2,999,100.00$, operating cost of $\$ 77,085,200.00$, and the interest on loan borrowed amounting to $\$ 407,000.00$. While the imputed cost on family occupied broiler pen amount to $N 835,000.00$ as family labour cost $N 852,000.00$. This sum the total cost of the entire production activities for large-scale broiler enterprise to $\$ 82,178,300.00$. Applying the net income model, the annual net income of large-scale broiler farmers in the study area amount

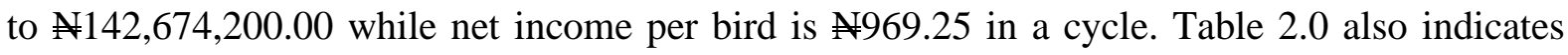
that for every additional $\$ 1$ used in the large-scale broiler farming in the study area, there will be $174 \%$ increase in return on naira used at the end of the year, all things being equal. Thus, large-scale broiler production in the study area is more profitable relative to small and medium scale production.

The analysis shows that broiler business is very profitable and confirmed the findings of various researchers (Ibrahim, Shettima, Sulumbe, \& Abdullahi, 2009; Nurudeen, 2012; Ojo, 2003; Tijani et al., 2012; Yusuf and Malomo, 2007) in different states of the federation who concluded in different studies that poultry business was highly profitable. Comparing the profitability of the three different scales of broiler farmers in Table 2.0, it indicates that the large-scale has the highest return on naira used with $174 \%$ followed by medium-scale with $47 \%$ return on naira used and the least was small-scale with $33 \%$ return on naira expended. The result reveals that the broiler farming in the study area is profitable and has the ability to offset its own cost, and still generate substantial return on naira used from every additional $\$ 1$ spent no matter the scale of operation. It is also noteworthy that large-scale broiler farmers enjoyed more internal economies of scale which results to positive cumulative effects on their return on naira expended.

\section{Net Income Per Bird Per Cycle}

Fig. 1.0 confirms that medium-scale broiler production raised the least income per bird in a cycle. Whilst table 2.0 reveals that the medium-scale has the highest number of production cycle per annum with annual net income preceding small-scale production.

\section{Non-Farm Income of Small, Medium and Large-Scale Broiler Farmers}

Table 3.0 reveals non-farm income of broiler farmers across different scale of operation from salaries/wages and remittances in the study area. From table 3.0, 52 small-scale farmers, 27 medium-scale farmers and 6 large-scale farmers engaged in non-farm economic activities. By 
indication, broiler farmers did not only generate income from broiler production, they also have other streams of income.

Comparing the value of average annual net income (in Table 2.0) of broiler farmers with the value of average non-farm income (in table 3.0) of broiler farmers across different scale of operation, it can be deduced that the non-farm income only serves as a supplementary income for broiler farmers in the study area. Non-farm income could be helpful and act as an income buffer for their household particularly when farm income becomes vulnerable to the risks and uncertainties related production.

\section{CONCLUSION}

Comparing the profitability of the three different scale of broiler farmers in Table 2.0, it indicates that the large-scale has the highest return on naira used with $174 \%$ followed by medium-scale with $47 \%$ return on naira expended and the least was small-scale with $33 \%$ return on naira expended. The result reveals that the broiler farming in the study area is profitable and has the ability to offset its own cost, and still generate substantial return on naira expended from every additional $\$ 1$ spent no matter the scale of operation. It is also noteworthy that large-scale broiler farmers enjoyed more internal economies of scale which results to positive cumulative effects on their return on naira expended.

Comparing the average annual net income of broiler farmers with the average non-farm income of broiler farmers across different scale of operation, it can be deduced that the non-farm income only serves as a supplementary income for broiler farmers in the study area.

\section{RECOMMENDATION}

In an attempt to rise the net-income of broiler farmers vis-a-vis more capital to scale-up broiler production, small and medium-scale operators are encouraged to diversify their productions with other livestock enterprises like layer production enterprise, turkey production enterprise and goat production enterprise.

Broiler farmers are encouraged to cultivate the culture of savings to enable them have enough capital for reinvestment and expansion as majority of broiler farmers are small-scale base.

This study revealed that feed cost is the major important single cost item associated with broiler production which could be attributed to high market prices of the broiler feed ingredients such as maize, groundnut, soy bean and wheat. To this effect, government should engage in PublicPrivate Partnership (PPP) to establish feed production plants in the 3 zones of the state that will integrate growing of feed ingredients such as maize, groundnut, soy bean and wheat as raw materials for feed production. This to a large extent will not only reduce the cost of feed for broiler farmers but also reduce unemployment and stimulate economic activities in the state. 


\section{REFERENCES}

Akinwumi, J. A., Degeye, T. A., Ikpi, A. E., \& Olayide, S. O. (1979). Economic analysis of Nigerian poultry industry. A study commissioned by the Federal Livestock Department, (FLD) Lagos.

Babalola, D. A. (2014). Risk preferences and coping strategies among poultry farmers in Abeokuta Metropolis, Nigeria. Global Journal of Science Frontier Research: D Agriculture and Veterinary, 14(5), 1.

Ehirim, N.C., Rhaji, M.A.Y., Oguoma, N.N.O., \& Onyeagucha, S.U.O. (2017). Assessment of poverty period of FADAMA 111 participants in Imo State, Nigeria. Asian Journal of Agricultural Extension Economics \& Sociology, 15(4), 1-13. https://doi.org/10.9734/AJAEES/2017/15122

Emaikwu, K. K., Chikwendu, D. O., \& Sani, A. S. (2011). Determinants of flock size in broiler production in Kaduna State of Nigeria. Journal of Agricultural Extension and Rural Development, 3(11), 202-211.

Ibekwe, U.C., Eze, C.C., Ohajianya, D.O., Orebiyi, J.S., Onyemauwa, C.S., \& Korie, O.C. (2010). Determinants of non-farm income among farm households in South East Nigeria. Researcher2(7), 49-52.

Ibekwe, U.C., Eze, C.C., Onyemauwa, C.S., Henri-Ukoha A., Korie O.C., \& Nwaiwu, I.U.O. (2010). Determinant of farm and off-farm income among farming households in South East, Nigeria

Ibrahim, A., Shettima, B.G., Sulumbe, I.M., \& Abdullahi, H. A. (2009). Economic Analysis of Poultry Egg Production in Kaduna North Local Government Area of Kaduna State, Nigeria. Proceedings of the $23^{\text {rd }}$ Annual National Conference of Farm Management Society of Nigeria 14-17. pp. 635-640

Ike, P.C., \& Ugwumba, C.O.A. (2011). Profitability of small-scale broiler production in Onitsha North Local Government Area of Anambra State, Nigeria. International Journal of Poultry Science, 10(2), 106-109. https://doi.org/10.3923/ijps.2011.106.109

International Fund for Agricultural Development (IFAD), (2001). The Challenges of Ending Rural Poverty, Oxford University Press, New York. 250Pp.

Knoema (2018). Nigeria - Production of poultry meat. Retrieved from https://bit.ly/31cfK9F on October, 2020.

Mgbakor, M. N. \& Nzeadachie C. E. (2013). Economic analysis of broiler production: A case study of Orumba South L.G.A of Anambra State, Nigeria. American-Eurasian Journal of Agronomy 6(2), 25-31. DOI: 10.5829/idosi.aeja.2013.6.2.1102 
Nurudeen, A.J. (2012). Economics and social characteristics of registered poultry egg producers in Ilorin, Kwara State. Russian J. Agric. Socio Econ. Sci. 11:11. https://doi.org/10.18551/rjoas.2012-11.03

Nwaru, J.C. (2007). Rural credit markets and resources use in Arable crop production in Imo State of Nigeria. Unpublish $\mathrm{Ph}$. D Dissertation, Michael Okpara University of Agriculture, Umudike, Nigeria.

Ojo, S. O. (2003). Productivity and Technical Efficiency of Poultry Egg production in Nigeria. Int.J. Poult. Sci. 2,459-464. https://doi.org/10.3923/ijps.2003.459.464

Okonkwu, W.I. \& Akubuo, C.O. (2001). Thermal analysis and evaluation of heat requirement of a passive solar energy poultry chick broader, Nigeria. J. Renew Energy, 9.1

Olorunsanya, E. O. (2004). Egg Farming Business in Kwara State, How profitable? Agrosearch, $6(1), 9-14$.

SAHEL (2015). An Assessment of the Nigerian Poultry Sector. http://sahelcp.com/anassessmentof-the-nigerian-poultry-sector/. SAHEL 11: 1-3.

Tijani, H., Tijani, B.A., Tijani, A. N., \& Sadiq, M.A., (2012). Economic Analysis of Poultry Egg Production in Maiduguri and Environs of Borno State, Nigeria. Scholarly Journal of Agricultural Science, 2(12), 319-324

Yusuf, S.A. \& Malomo, O. (2007). Technical Efficiency of Poultry Egg Production in Ogun State: A Data Envelopment Analysis (DEA) approach. Int. J. Poult. Sci.,6(9), 627-629. https://doi.org/10.3923/ijps.2007.622.629 
Journal of Agriculture and Food Sciences Volume 18, Number 2, October 2020, pp $98-108$

\section{APPENDIX}

Table 1.0: A breakdown of sample selection of broiler farmers for the study

\begin{tabular}{|c|c|c|c|c|c|c|c|}
\hline \multirow{2}{*}{ Zones } & \multirow{2}{*}{$\begin{array}{l}\text { Number } \\
\text { of } \\
\text { registered } \\
\text { LGA's }\end{array}$} & \multirow{2}{*}{$\begin{array}{l}\text { Number } \\
\text { of } \\
\text { Selected } \\
\text { LGA's }\end{array}$} & \multirow{2}{*}{$\begin{array}{l}\text { Number } \\
\text { of } \\
\text { selected } \\
\text { broiler } \\
\text { farmers }\end{array}$} & \multicolumn{3}{|c|}{$\begin{array}{l}\text { Number of retrieved responses } \\
\text { per scale of operation }\end{array}$} & \multirow{2}{*}{$\begin{array}{l}\text { Total No. } \\
\text { of } \\
\text { responses } \\
\text { retrieved }\end{array}$} \\
\hline & & & & $\begin{array}{l}\text { Small- } \\
\text { scale }\end{array}$ & $\begin{array}{l}\text { Medium- } \\
\text { scale }\end{array}$ & $\begin{array}{l}\text { Large- } \\
\text { scale }\end{array}$ & \\
\hline Owerri & 10 & 3 & 35 & 26 & 9 & 0 & 35 \\
\hline Orlu & 7 & 3 & 36 & 15 & 15 & 6 & 36 \\
\hline Okigwe & 5 & 3 & 42 & 15 & 11 & 3 & 29 \\
\hline Total & 22 & 9 & 113 & 56 & 35 & 9 & 100 \\
\hline
\end{tabular}

Source: Field Survey Data, 2018

Journal of the Faculty of Agriculture and Veterinary Medicine, Imo State University Owerri website: www ajol.info; Attribution: Non-commercial CC BY-NC 
Table 2.0: Annual Net Income of Broiler Farmers across the Three Scale of Operation

\begin{tabular}{|c|c|c|c|c|c|c|c|c|c|c|}
\hline \multirow[b]{3}{*}{ Items } & \multicolumn{10}{|c|}{ Scale of Operation } \\
\hline & \multicolumn{5}{|c|}{ Small-scale } & \multicolumn{2}{|c|}{ Medium-scale } & \multicolumn{3}{|c|}{ Large-scale } \\
\hline & Details & Qty & $\begin{array}{l}\text { Unit price } \\
(\mathrm{N})\end{array}$ & $\begin{array}{l}\text { Amount/year } \\
(\mathrm{N})\end{array}$ & Qty & $\begin{array}{l}\text { Unit } \\
\text { price }(\mathrm{N})\end{array}$ & $\begin{array}{l}\text { Amount/year } \\
(\mathrm{N})\end{array}$ & Qty & $\begin{array}{l}\text { Unit price } \\
(\mathrm{N})\end{array}$ & $\begin{array}{l}\text { Amount/year } \\
(\mathrm{N})\end{array}$ \\
\hline Sales & $\begin{array}{l}\text { Table } \\
\text { Birds }\end{array}$ & 15,215 & $2,023.12$ & $30,781,560.00$ & 34,250 & $1,604.94$ & $54,969,250.00$ & 73,600 & $3,055.06$ & $224,852,500.00$ \\
\hline Revenue & & & & $30,781,560.00$ & & & $54,969,250.00$ & & & $224,852,500.00$ \\
\hline \multicolumn{11}{|l|}{ Cost } \\
\hline Fixed inputs & DV & & & $727,487.50$ & & & $760,588.00$ & & & $2,999,100.00$ \\
\hline Op Cost & & & & $19,445,343.00$ & & & $33,063,165.00$ & & & $77,085,200.00$ \\
\hline \multirow{2}{*}{$\begin{array}{l}\text { Imputed } \\
\text { cost }\end{array}$} & FOP & & & $1,262,100.00$ & & & $1,457,750.00$ & & & $835,000.00$ \\
\hline & $\mathrm{FL}$ & & & $1,349,700.00$ & & & $1,926,750.00$ & & & $852,000.00$ \\
\hline $\begin{array}{l}\text { Interest } \\
\text { paid/year }\end{array}$ & & & & $306,500.00$ & & & $145,000.00$ & & & $407,000.00$ \\
\hline Total cost & & & & $23,091,130.50$ & & & $37,353,253.00$ & & & $82,178,300.00$ \\
\hline NI/Annum & & & & $7,690,429.50$ & & & $17,615,997.00$ & & & $142,674,200.00$ \\
\hline $\mathrm{NI} / \mathrm{B} / \mathrm{C}$ & & & & 252.73 & & & 171.45 & & & 969.25 \\
\hline RON & & & & 33.3 & & & 47.16 & & & 173.62 \\
\hline \multicolumn{4}{|c|}{$\begin{array}{l}\text { Source: Field Survey Data } 2018 . \\
\text { Small-scale Average cycle/year =2; } \\
\text { Medium-scale Average cycle/year = 3; } \\
\text { and Large-scale Average cycle/year =2 }\end{array}$} & $\begin{array}{l}\text { Average unit pric } \\
\text { Small-scale: } 120 \\
\text { Medium-scale: } \\
\text { Large-scale: }\end{array}$ & $\begin{array}{l}\text { /scale of } p \\
3.12 \\
1604.94 \\
55.06\end{array}$ & roduction/ & & \multicolumn{3}{|c|}{$\begin{array}{l}D V=\text { depreciated Value } \\
F O P=\text { Family Occupied pen } \\
F L=\text { family Labour } \\
O P \text { Cost = Operating Cost } \\
N I=N e t \text { Income } \\
N I / B / C=\text { Net Income/Bird/Cycle } \\
R O N=\text { Return on Naira used }\end{array}$} \\
\hline
\end{tabular}




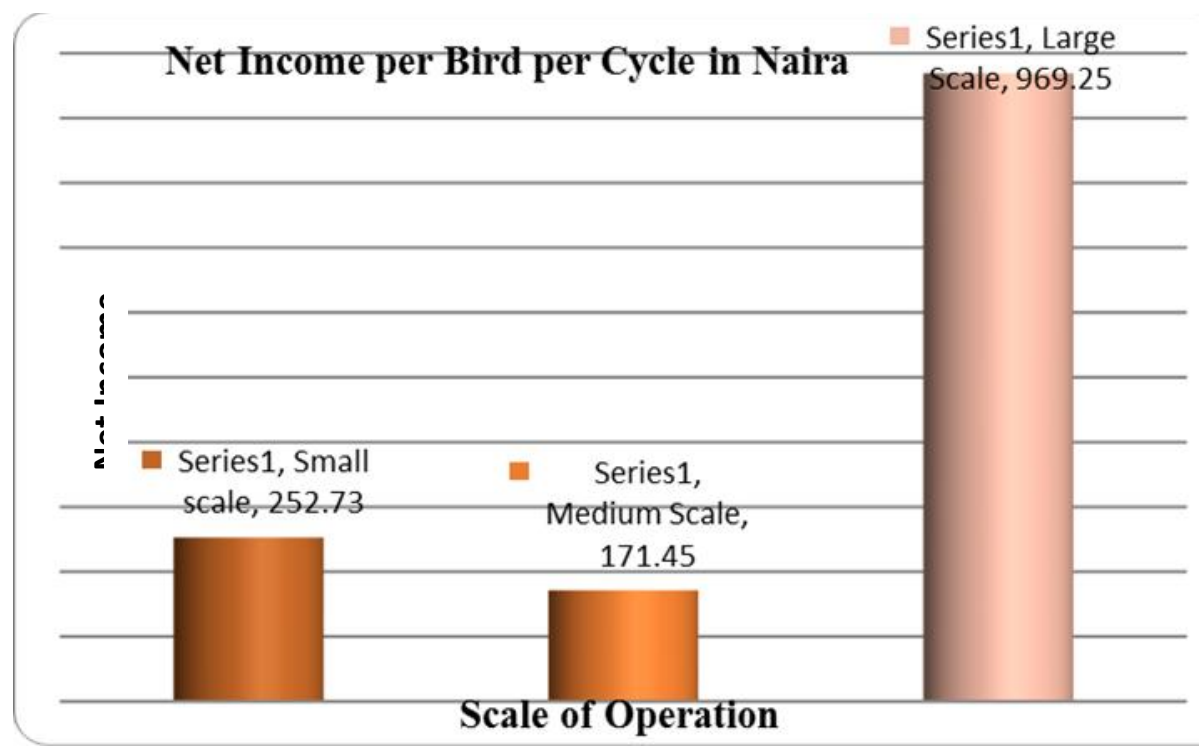

Fig. 1.0 Net income per bird per cycle in naira for different scale of production

Table 3.0: Non-farm Income of Small, Medium and Large-scale Broiler Farmers Scale of Operation

\begin{tabular}{lccc}
\hline Variables & \multicolumn{3}{c}{ Income (N /Annum) } \\
& Small & Medium & Large \\
\hline Salaries/wages & $4,835,600.00$ & $4,826,000.00$ & $1,590,000.00$ \\
Remittances & $2,510,100.00$ & $2,900,000.00$ & $785,000.00$ \\
Total Income & $7,345,700.00$ & $7,726,000.00$ & $2,375,000.00$ \\
No of Farmers & 52 & 27 & 6 \\
Mean Annual Net Income (N/Year) & $\mathbf{1 4 1 , 2 6 3 . 0 0}$ & $\mathbf{2 8 6 , 1 4 8 . 0 0}$ & $\mathbf{3 9 5 , 8 3 3 . 0 0}$ \\
\hline Source: Field Survey Data, 2018 & & &
\end{tabular}

